\title{
Historiography of Cinephiles in Thailand
}

\author{
Sasawat Boonsri \\ Wikanda Promkhuntong (Trans.)
}

Amongst film audiences in Thailand, there is a group that follows the new releases enthusiastically. They watch many films in the course of a week and do not only focus on films in the cinema but also search for places to watch alternative movies. Forming in the 1970s, these people are now known as "Thai Cinephiles". They started off as regular audiences at screening events before becoming film critics, programmers and curators. This practice significantly expands the awareness of alternative cinema in Bangkok and other parts of Thailand.

This paper traces the activities of Thai cinephiles from the late of 1970 s when they first met each other at cultural institutions that screened alternative cinema, to the 1990s when conversations evolved around video shops and film festivals at shopping malls. The age of digital also saw Thai cinephiles took into writing, promoting and creating diverse content across various platforms from blogs, message boards to Facebook. Their practice/activism across different generations shared through interviews reveals the principle of sharing the good stuff they found and building new generation of directors and audiences. This historiography provides an alternative history on Thai film culture that bridges existing writings on the Thai new waves and limited research in the Thai language on audience motivations and cinema going.

Keywords : Thai Cinephile, Thai film culture, historiography, alternative cinematheory, contextualization of theory, indigenous, vernacular and hybrid theory

Film Studies as an academic field in the Anglo-European context has been widely expanded beyond the focus on film texts to various contextual enquiries including cinema-going culture and cinephiles studies. In the context of Asia, particularly Thailand, academic research into these expanded areas is still limited. My survey of works on audiences of Thai films reveals that the majority of writings are quantitative research of audience satisfactions taken at different geographical locations (see Kamsopa, 2007; Jandeeriam, 2008) with the exception of Praweenamai Baikloy's thesis (2003). Baikloy's work discusses the reasons why audiences watched independent films in Thailand. The thesis sheds lights on supporters of independent cinema in the pre-internet era but does not cover the group which I refer to in this article as "Thai cinephiles" who arguably played a very important part in fostering alternative film going culture in Thailand, particularly in Bangkok. While they are not the only group of self-identified 
cinephiles in the country, I argue that this group is one of the longest running supporters of Thailand's alternative film scene. Their activities can be traced back to the 1970s until today. It is important to note that I came to be part of this group sometime in 2007, starting with online communications with active members and subsequently through personal involvement in group activities. Hence, the writing of this article inevitably engages with the personal views gained through direct contact with the members. With permission from individuals in the group to conduct in-depth-interviews with them about their film viewing and different related activities, this article hopes to provide the currently missing piece of history on cultural activities and key players that fostered alternative film culture in Thailand.

Taking cinephilia as a historical subject of study in the same manner as Kristian Keathley (2006), the paper provides a chronological history of Thai cinephilia and reflects on how cinephile practices engage with the European root of the term. With limited published archival documents regarding early activities of the group, my project gathered information through interviews with cinephiles who turned from a film viewer to a film programmer or a film critic. The subjects I interviewed can be divided into two groups. The first group is comprised of the cinephiles who were active cinema-goers in the pre-Internet years in the 1970s and 80s when alternative cinema was mainly accessible via cultural institutes. The interviewees in this group are Kriangsak Silakong, Suparb Limtapathip, Manotham Thiamthiabrat, Uthis Haemamool, Pornchai Viriyaprapanon and Sonthaya Subyen. The second group focuses on those who were or are active on the internet platforms since the 1990s, particularly those who have written blogs and use various social media to promote alternative film culture. Members of this latter group that I interviewed are Kajornpong Bunthurngsuk, Jit Phokaew, Wiwat Lertwiwatwongsa, Kanchat Rangseekansong, Nawapol Thamrongratanarit and Chayanin Tiangpittayakorn. While there are a small number of female members in the group, the majority of those involved are male or male who identified themselves as gay. The small number of female cinephiles may be due to various socio-cultural circumstances and my limited connections to them, which is a limitation of the research. The cinephiles whom I had the opportunity to interview vary in terms of age and occupation. Many joined the group during their studies or as they started working.

As mentioned, the majority of members were or are based in Bangkok. This reflects the development of organized cinema and cultural activities which tend to be clustered in the capital center. The provinces have been given less importance in developmental policies which resulted in the cluster of governmental offices, private companies and major cultural institutes in Bangkok and nearby areas (Tangchonlatip, 2007). While films events are 
now expanded to major provinces such as Chiang Mai in the North, Nakhon Ratchasima in the Northeastern part, or Phuket in the South, the majority of activities are still based in Bangkok. It is also important to note that I use the term cinephiles to refer to people I interviewed throughout the article. However, the actual use of the term in Thailand started no more than ten years ago. The early use of the term can be traced back to the Pantip.com message board (started in 1997) with a reference to Prince Chatrichalerm Yukol, who has been a prolific Thai film director since the 1970s ("72 years Prince Chatrichalerm Yukol," 2014).

\section{Characteristics of Thai cinephiles}

Thomas Elsaesser (2005) separated cinephiles into two generations. The first generation emerged around 1920-1970. Members kept aloof from the universities, spent times at cine-clubs and kept their faiths with auteur cinema and the big screen. The second generation, which emerged around 1980s-90s, was interested in all kinds of movies accessible via new technologies such as DVDs and the internet. Both groups exist as communities but have different shared experiences and modes of film appreciation due to changes in film viewing circumstances.

In Thailand, members of the group I interviewed started their film activities as early as the 1970s. These early cinephiles shared the same characteristics of following new releases enthusiastically. They watched many films in the course of a week and not only focused on films in the cinema but also searched for places to watch alternative movies. Resonating with Elsaesser's (2005) first generation of cinephiles who had close ties with specific cine clubs, the sites that early Thai cinephiles gathered are cultural institutions including the Goethe-Institut and the Alliance Française. These sites continue to provide alternative film screening programs until today. More recent cultural venues include the Thai Film Archive. Members of the group also followed local film festival programs closely. Resonating with Jonathan Rosenbaum's (2010) discussion of cinephiles as those who write about cinema, the key distinction of the group of latter generation of Thai cinephiles explored in this paper is the active participation in writing and circulating information about movies among themselves and in the public domains. While different generations engage in different activities, all of the interviewees have been active in fostering film cultures in Thailand.

\section{Cultural Spaces for Early Thai Cinephiles}

The Thai cinephile community which I interviewed started small in Bangkok in 1977. Those involved discussed their fond memories of eating together after the movies. Conversations over food were all about the movie(s) they 
saw. Manotham Theamtheabrat, a banker and film critic as well as a parttime lecturer in film history is part of this early group. He is well-respected in the Thai film critic scene for his good memory. Theamtheabrat can recall in great details of the film programs at different cinemas in the premultiplex era. He is also amongst audiences who frequented foreign cultural institutes when they were the sole spaces that screened alternative movies. Theamtheabrat (personal communication, March 13, 2017) recalled the weekly screening programs which he frequented below:

Monday at the Alliance Française

Tuesday at the British Council

Wednesday at the Goethe-Institut

Thursday at the American University Alumni Association (AUA)

Friday at the Japan Foundation, taking turn with the Thai Film Archive

Theamtheabrat (personal communication, March 13, 2017) noted that in 1977 the majority of people who attended film screenings at cultural institutes were foreigners and a few Thais. The Thais who were there did not know each other and they often brought friends along to make them feel less awkward. Theamtheabrat got to know other people via Gerard Fouquet, who greeted those who attended the screenings. Since there were not many Thais, they soon recognized each other and gradually started talking amongst themselves. These early cinephiles include Theamtheabrat, Dome Sukkhawong (the founder of the Thai Film Archive), Dulyasit Niyomgul (a filmmaker), Sonthaya Subyen (the founder of a well-known film club in Bangkok), Pornchai Viriyaprapanon (a writer and film critic), Suparp Rimthepathip (a founder of Bioscope film magazine), Siwaporn Pongsuwan (a screen writer) to name but a few. The group formally got together at the end of the busy year of 1983 during which time there was the screening to celebrate the $50^{\text {th }}$ Anniversary of Thammasat University. The following year, there was also an experimental film workshop which brought people together. Viriyaprapanon (personal communication, July $13,2017)$ humorously commented that the main shared characteristics of the group members was that they were "unusual, normal audiences that wouldn't come to watch these films." Viriyaprapanon's remark highlights the way members of this group connected through the film viewing habit, and through their tastes or cultural preferences which differed from those of general film audiences. Other shared traits mentioned were selfidentification as introverts, and the watching of as many films as possible.

Apart from their film viewings habits, this group was also formed 
around their interest in knowledge sharing. At the time, there were limited channels to learn about cinema. Sources of information available were mainly from text books in the English language at university libraries or English language film magazines. Opportunities to see alternative cinema were also rare. Hence, cultural institutions played an important role in fostering alternative cinema (which were their own national cinemas) and connecting these Thai audiences with new films. With limited resources, the meetings to exchange knowledge about cinema were important to the growth of the group. As mentioned earlier, conversations about films were shared over a meal after the screenings. The usual place for meetings was Theamtheabrat's house on Pun road in Silom, downtown area of Bangkok. In addition to the discussion about films which they saw together, many also shared their aspirations of making their own movies (S. Subyen, personal communication, July 4, 2017). Theamtheabrat (personal communication, March 13, 2017) had a lot of information to share with the group including his own interpretations of the films, which led to the group's practice of film criticism. This kind of knowledge sharing addressed the limitation of studying film in Thailand at the time, which focused on filmmaking practice. Apart from the Communication Arts Department of Chulalongkorn University, and the Faculty of Journalism and Mass Communication, Thammasat University, there were no other organizations that offered space for film criticism for the public. The shared curiosities about cinema of this generation of cinephiles led to the formation and relationship building of the group. Subsequently, many members have also become film critics.

In 1986, Subyen, one of the members, went to continue his studies in the UK. During this time he sent film-related news to his cinephile friends in Thailand, along with leaflets and books about cinema. Subyen (personal communication, July 4, 2017) also made a copy of films that he rented in the UK in order to screen them for friends upon his return. Revealing cinephile comraderie relations, Subyen said that he always thought of his friends when watching a film that they might not have seen. The enthusiasm for new films also led many cinephiles to become film collectors and organizers of film screenings.

By the late 1980s, Theamtheabrat and other cinephiles started to help with the work of the Thai Film Archive as assistant programmers. The establishment of the Thai Film Archive would not be possible without the key cinephile, Dome Sukkhawong, (as cited by Theamtheabrat, 2017) an avid film goer who successfully pushed for the establishment of the national film archive to preserve film and promote cinema to the public. Initially, the Thai Film Archive was set up in 1984 as part of the National Library of Thailand Office under the Fine Arts Department, Ministry of Education 
(History of Thai Film Archive). It was later moved to be with the Ministry of Culture in 2002 and was established as a Public Organization in 2009. The organization has played a key part in fostering film cultures in Thailand through various activities since then ("History of Thai Film Archive," n.d.). It is evident that by the 1980 s, many cinephiles had turned from film viewers to programmers and curators. The key contribution of Sukkhawong and the Thai Film Archive, along with cinephiles who collaborated with Sukkhawong, was the collection and restoration of a lot of Thai films for public viewing, including the works of legendary filmmaker Rat Pestanyi. (Dome Sukkhawong as The Head of Thai Film Archive, Thai Film Archive, 2018). The Thai Film Archive has also played an important role in fostering new filmmakers with the Thai Film Foundation by hosting an annual short film competition. The event has provided a platform for high school and college students, as well as public audiences, to submit their works. The event has become a competitive space for many young filmmakers. Many went on to make feature-length films after receiving the award (e.g. Boonsong Nakpoo and Nawapol Thamrongrattanarit). The event has also been a place where cinephiles could meet up. Chalida Uabumrungjit (personal communication, September 15, 2017), the current director of the Thai Film Archive mentioned informally that "all of us at the archive have been/are cinephiles." Through this development, it is evident that members of the Bangkok cinephile community have started to create communal spaces and activities that produce new generations of cinephiles and filmmakers.

\section{The Transition to Cineclub and VHS Shops}

Once Subyen returned from his studies in the UK in 1994, he started the Duangkamol Film House (Duangkamol was then a well-known chain bookstore). His intention was to organize an activity to draw audiences to the bookstore. The film screenings were held at the Seacon Square branch of the bookshop in Bangkok. The organizers which initiated by Subyen named themselves Filmvirus (as cited by Subyen, 2017).The films that Subyen screened included those that he copied while he was in the UK, and films specifically ordered for the screening in VHS and laserdisc formats. Occasionally, there were also $16 \mathrm{~mm}$ film screenings. These film club screenings expanded the work of cultural institutions and had good turnout. On average, there were $10-15$ people attending. Certain films attracted more people, although sometimes there were only 4-5 people in an audience. While the numbers were unpredictable, the screenings fostered a new generation of cinephiles instead of the earlier group who had shifted their focus to their careers. The new faces include Uthis Haemamool, a notable SEA Write award-winning author; Jit Phokaew, an avid film viewer; 
Kriengsak Silakong, a director of the World Film Festival of Bangkok; Alongkot Maiduang, a film critic; Soraya Nakasuwon, a filmmaker; Paisit Punpruksachat, a sound designer; and Apichatpong Weerasethakul, a notable filmmaker.

By 1997, the screenings at cultural institutions went into decline (Baikloy, 2003). Many places stopped the event or arranged their programs with multiplexes. Many audiences also said to have enough of cinema and went on to do other things (U, Haemamool, personal communication. April 27, 2017). Around the same time, there was a growing number of shops that sold VHS tapes, making independent cinema more accessible. Many audiences shifted to watching films at home, instead of going out. The mushrooming of stores that sold independent films in Bangkok were known through names such as Lukmaew at MBK shopping center, Rex at Pratunam area, Van Video at the weekend JJ market, and Fame at Klongsarn market. These shops invested in buying foreign films which won awards and critical acclaims and made copies of them for sell. They also invested in making Thai subtitles and packaging. The key venue to find films was at Van Video which sold films on the weekend. The practice of making a copy of films for cinephiles by Van Video resonates with the earlier practice of Subyen. While the activity may be deemed problematic in relation to copyright concerns, it could be stated that the key factor that led to this kind of activity is the lack of access to award winning independent films. This circumstance resonates with the discussion of pirate video, VCD and DVD which had an important role in expanding Asian viewers for films which were not promoted by the multiplexes due to the presumed lack of commercial return (see Pang, 2006). While the commercial aspect of the Van Video complicated the non-profit cinephlilic practice, the technology allowed for wider access of alternative cinema for Thai cinephiles.

\section{The Formation of New Generation through Web board and Blog}

The growth of the internet has changed the landscape of cinephiles all over the world including in Thailand. In Thailand, the Internet boom started in the mid 1990s and spread around the country in the early 2000s. Influential platforms in the early days of the Internet were message boards and blogs. Many second generation cinephiles I interviewed mentioned about watching independent films at home and attended festivals only to watch well-known films. Additionally, they started to exchange knowledge and their thoughts on specific films via an online message board or as commonly referred to in Thailand as a webboard. At the time, Bioscope film magazine had a vibrant webboard which members posted screening programs and exchanged their views on cinema. While members posted with their pseudonyms, common 
pseudonyms were later become well-known in the community through their real names. Members included Graiwoot Chulphongsathorn, a former editor of Bioscope who is now a film academic and curator; Kanchat Rangseekansong, a writer and a guest film lecturer who has been writing under the name merveilesxx; Wiwat Lertwiwatwongsa, a pharmacist and the main curator for the Filmvirus group who has been writing under the name Filmsick; and Jit Phokaew, a news translator who has been watching alternative cinema and Thai short films since 1995. Phokaew noted in an interview (personal communication, April 16, 2017) that in addition to the Bioscope webboard, there was a gay forum called SQ 28 with a film section called Screen Out which was well-known. Another place where cinephiles shared the news online was Pantip.com, which to date is the longest running webboard in Thailand. According to Lertwiwatwongsa (personal communication, January 28, 2017), writing a blog and participating in a webboard created a virtual community formed through the shared feeling that "there is someone who likes the same thing as us." Although this group of cinephiles has been able to rent/buy DVDs of different types of film and they did not meet to watch movies as often, they still shared some characteristics with the early group. Once these new cinephiles met each other, they were too shy to talk to each other. Subsequently they tried to overcome this by posting in one of the forums along the line of "Are you that person? Next time I will come and talk to you." Online blogs facilitated exchanges through comments as well as a new post in response to a specific writing. A common comment on the blog was a note that the reader saw the writer at an event but was too shy to say hello. Hence, the webboard and blog were initial platforms for personal introduction.

New practices also emerged at the time such as writing to invite others to join a film event on a webboard. Afterwards, those who joined would post their thoughts about the films they saw on the same site. These writers also uploaded their writings on their personal blogs. Phokaew and Rangseekansong noted in their interviews that the reason they kept their own blogs was to organize their own writings for future search since the webboard did not facilitate this. Common blog services that cinephiles used were bloggang.com and exteen.com (now defunct). These cinephiles also read others' blogs to find out what their friends think of a specific film. This practice extended to some new readers who did not use the Bioscope webboard. As blogs allow longer content, the writings posted were often in the form of an essay. Some cinephiles who previously attended the film criticism training class by the Thai Film Archive also started writing in the form of film criticism (e.g. Kanchat Rangseekansong). The platform then became a place to showcase their skills. This climate expanded the previously 
limited space to discuss films via film magazines. It also introduced new writers who were/are based outside Bangkok. As a new member to the group then, I started my writing with the blog format while living in Chiang Mai, in the North of Thailand. My writing then was about different film events that took place in the province. Similarly, Lertwiwatwongsa also started and has continued his writings from his home town in Phuket. Apart from the webboard and blog, the group of 1990s cinephiles I interviewed also used email and MSN chat program to arrange meetings at film festivals. Phokaew and Chulphongsathorn were amongst the cinephiles who acted as intermediators between cinephiles in real life. Phokaew (as cited by Thamrongrattanarit, 2017) noted that he is the first person who went to talk to Nawapol Thamrongrattanarit (now a well-known filmmaker in Thailand and Asia), when he started attending screenings at cultural institutions. At the end of the screenings, this new generation of cinephiles also continued the practice of going for a meal together.

This group of cinephiles gathered at the New Light Restaurant in the Siam Square shopping district. Members said that the reason for choosing this place was because of its location. New Light was located at the center of town and not far from the screening venues. At this time, film events started to be held at multiplexes in the shopping malls near Pathumwan and Siam Square areas. New Light was the top restaurant on the list as it was not expensive, since many new cinephiles were still studying or had just started working. One other reason for choosing this restaurant was the closing time. Among the criteria of a meeting place for the group is that it has to open until late, since many film festivals finished their last screening at around 9 p.m. Travel time and ordering time had to be included. As New Light was later closed down, the meeting venue later changed to other restaurants that met the same criteria. Current places that run film programs are the Bangkok Art and Cultural Center in Pathumwan area, and shopping malls connected to the BTS sky train such as Central World. Another new alternative venue is the Reading Room (along Silom 19 road). Subsequently, the meeting point has been changed to Hong Teong Long aka the red lanterns, named after the red lanterns decoration at the front of the restaurant. This Chinese restaurant is on Narathivas Road not far from the screening venues and does not close until late. Another alternative food venue is an affordable Northeastern restaurant in Ratchathewi area, accessible via a sky train. While cinephiles have also engaged in other film related activities on and offline since 2000s, as will be discussed further in the next sections, the early online communications and the post screening meals were important for the continuation of the group and the expansion to new members. 


\section{Expanded Online Activities to Promote Alternative Cinema}

Apart from online writing and conversations over food, the availability of video recording devices led to the use of "video commentary" or "video comment" as a way to promote films. Video comment practice started during a marathon screening of short films submitted for the Thai Short Film \& Video Festival organized by the Thai Film Archive and Thai Film Foundation. A group of audiences called Yod-sean-suk-haneg (ยอดเซียน ซักแห้ง), who were the frequent attendees of the festival and had previously submitted works for competition, started the practice in 2009. Five members of this group were: Dhan Plewtianyingthawee, director of $\mathrm{Hal}$ Film Distribution; Nattha Homsub, independent filmmaker and guest lecturer; Kamthorn Bunteungsuk, managing director at Hal Distribution; Kajornpong Bunturngsuk; and Sarin Thaksinawisut. Homsub started the video commentary in order to express his own feelings towards the film he watched after being inspired by Phokaew and Lertwiwatwongsa, who previously wrote their thoughts on personal blogs and the Bioscope webboard. Homsub also tried to collect relevant information about a particular short film including its unique characteristics and points of interest. Homsub and friends then shared photographs of these works on the now defunct Multiply platform, which focused on visual content.

In 2009 at the $13^{\text {th }}$ marathon screening of short films held at the Bangkok Art and Cultural Center, the Yod-sean-suk-haneg group decided to make a video commentary since writing about these films individually required a lot of effort and there were not many readers. The concept of the video commentary was to "say, in whichever way, about your favorite films, or the highlight of the day, or the film that you hated most or felt annoy about it" (K. Bunturngsuk, personal communication, March 31, 2017). The aim was to give some feedback to directors who were sending films for the competition. There were many directors who missed the screening of their own works and did not have a chance to observe audience feedbacks because the marathon screening program was run in alphabetical order. The screening starts from 4 p.m. to 8 p.m. everyday. However, in the $17^{\text {th }}$ to $21^{\text {st }}$ marathon screenings, there were more than 600 short films each year. Hence, the programmers altered the screening times from 11 a.m. to 8.30 p.m. everyday (except Monday). During these years, it was difficult to attend all the screenings. The commentary communicated to the directors that there were audiences for their films.

Kamthorn Bunteungsuk (personal communication, March 31, 2017) noted that he used his mobile phone to record people who expressed their views about the films. At the beginning, Dhan Plewtianyingthawee was the interviewer asking people who were frequent attendees, such as the 
previously mentioned Jit Phokaew, Kanchat Rangseekansong, Graiwoot Chulphongsathorn, Nawapol Thamrongrattanait, and others, including film critics Chayanin Tiangpitayagorn and Ekkarat Monwat, and filmmaker Alwa Ritsila. Afterwards, Plewtianyingthawee compiled the interviews, adjusted the sound and uploaded it on killpidz channel on YouTube. The video commentary was made every day for the duration of the festival. Younger cinephiles were also featured in the interviews, including: Ratchapoom Boonbunchachoke, a screen writer and a short film maker; Nontouch Promsri, who works in the film industry; and Korn Kanokkeekarin, an experimental filmmaker and the projectionist for the marathon screening of the $17^{\text {th }}-20^{\text {th }}$ Thai Short Film Festival and Nattawoot Nimitchaikosol. The majority of audiences who watched the video commentaries were the directors of the short films screened on the day, and their friends. There were around 100 views per video. These videos did not attract much comments but when some of the directors met someone in the videos in person, they usually asked for more comments about their films.

Alongside the video commentary, another activity in relation to the Short Film Festival was the Marathon online website. It was organized by Tiangpitayagorn as a site that provided links to the films screened at the festival, gathered from various channels including Youtube, Vimeo, and Google Drive provided by the filmmakers. Tiangpitayagorn searched for these films online and shared whatever information was available. The daily post offered content for those who were not able to attend the screenings or those who were not in Bangkok. It also provided a PR platform for the films. Although the marathon online has shifted to a Facebook page around 2012, the YouTube channel is still available to provide archival records of the reception of contemporary shorts films which were hard to find in Thailand.

In addition to promoting short films of up-and-coming filmmakers through promotional activities online, one other key feature of the group of Thai cinephiles I interviewed, which resonates with the previous generation of cinephiles is the transition from a writer and promoter to a film programmer. Since 2000, Lertwiwatwongsa has taken the role of Subyen in running the activities of the Filmvirus group. Lertwiwatwongsa was introduced to the Filmvirus through the magazine Film View and the screenings of films at Thammasat University where he met Subyen. Lertwiwatwongsa was also introduced to short films via the marathon screening. He was particularly interested in shorts that were not selected for the final round. This led him to screen the selected shorts separately after consulting with Subyen. Lertwiwatwongsa started his Filmvirus program at the Chamchuri Art Gallery to celebrate the $13^{\text {th }}$ anniversary of Filmvirus group. He collaborated with Phokaew and presented the shorts under the 
name Filmvirus Wildtype. The program has become a long running short film program until today. The venue for screening these shorts has since changed to the Reading Room with the support of owner and founder Narawan Pathomvat. Ultimately Pathomvat has also become a key female member of Filmvirus. Since 2015, Chayanin Tiangpitayagorn has also stepped in to become a programmer. The key criteria for selecting shorts in this program can be categorized into two groups: shorts screened at the marathon screenings which were not selected for the final round but made interesting impressions, and shorts which the directors submitted especially for the program. Lertwiwatwongsa (personal communication, January 28, 2017) noted that these shorts were the ones that Phokaew saw at the festival but he himself missed as they did not make it to the next round. These shorts, according to Lertwiwatwongsa, were difficult to evaluate based on artistic criteria and were sometimes questioned if they were really cinema. They are not likely to be selected for a festival or a gallery. Hence, Filmvirus Wildtype has made it their mission to screen these works.

Another aim of the Filmvirus Wildtype project is for the selected films to be in public discussions in order to send a message to the filmmakers that there are audiences and feedback for their films, in order to encourage them to continue working. Filmvirus has also extended their program to screen medium-length shorts (30-60 minutes) which are difficult to find a screening venue for (the general length accepted for a short film festival is no longer than 30 minutes and these films are not long enough to be feature films). Lertwiwatwongsa (personal communication, January 28, 2017) highlighted the difficulty for filmmakers in getting a screening venue which led to the quick disappearance of these shorts from the public memory. These longer short films gained longer shelf life through the Filmvirus Middleclass project which runs bi-annually and has so far received good feedback.

As a curator for Filmvirus, Lertwiwatwongsa also had opportunities to screen these films overseas. Similar to Subyen, Lertwiwatwongsa's (personal communication, January 28, 2017) aim has been to expand audiences for alternative cinema in Thailand. Hence, Lertwiwatwongsa also sought out short films from different countries to screen for local audiences under the Filmvirus Rhizome program. Filmvirus activities also included different collaborative projects such as the work with Japanese curator Keiko Sei to screen films from Myanmar and Czech Republic. All of these events were/ are free for the public and run on a voluntary basis. Recently, the group has asked for donations for the Reading Room, to contribute to the electricity cost and the accommodations for the staff. Filmvirus continues to operate until today, with new cinephiles who are still studying or have recently graduated ready to help with the projects. 
It is important to note that the film screening projects run by cinephiles were expanded beyond the longest running Filmvirus group. Another established group was Third Class Citizen, mainly run by Kanchat Rangseekansong and Nawapol Thamrongrattanarit who knew each other via blog. Third Class Citizen started in 2008 when events run by cinephiles began to emerge. The name Third Class Citizen alludes to films which were neglected. Thamrongrattanarit (personal communication, March 10, 2017) wanted to start a project by inviting 30 short filmmakers to create a 3-minute long film under the theme "2008" (observations about the year 2008). At the end of the project, there was a screening party where filmmakers got to meet each other. Thamrongrattanarit contacted people through the network of cinephiles at the Thai Film Foundation event and the World Film Festival of Bangkok. From that initial idea, both Rangseekansong and Thamrongrattanarit extended the project by screening short films once a month. The programmers selected short films of one filmmaker at a time. This gave an opportunity for audiences to see shorts of an established Thai auteur such as Aditya Assarat. At the end of the screening, there was also a Q\&A with the filmmaker. The venue for this screening was at the office of Bioscope magazine. Rangseekansong (personal communication, April 22, 2017) noted that both Thamrongrattanarit and himself screened films almost every month at the start as they did not have demanding jobs and there was no cost in running the event. Third Class Citizen had good turnout to their events. However, as the organizers grew busier, the event was reduced to a podcast that features a filmmaker talking about a new film being released. While Third Class Citizen ended their screening program, other projects have started such as Sharescreen by Patchara Lamtrakul, a filmmaker and owner of the production house Don't Panic. The project was also short-lived due to Lamtrakul's increasing work load. Another group mentioned in the interview was initiated by Thunska Pansittivorakul.

It could be said that despite the changing platforms and personal circumstances, the shared interests of cinephiles in organizing screening events and making information accessible online continue. These works have expanded the life-cycle of underexplored films and new filmmakers by introducing them to more audiences. While new participants joined the cinephile community, there are also long-running members such as Theamtheabrat, Subyen and Phokaew who continue to be part of the cinephile group until today. The final section of this paper discusses cinephile activities on Facebook, the most used platform for publicity of alternative films at the time of writing. 


\section{The Rise of Facebook as a Cinephile Space in Thailand}

By 2007, Facebook has begun to replace web board for cinephile communications in Thailand. Facebook facilitates the community of cinephiles through the friend network and nearby event functions. Many people got to know each other on Facebook before meeting in real life at film festivals. Those who previously attended the screening alone started to meet up with new friends, which led to the expansion of the cinephile network. Through this platform, new practices also emerged, such as new forms of film criticism and rating.

Phokaew is one of the cinephiles who always gives a score to the film he likes on his Facebook review. He remarked that this practice is the extension of those used in film magazines (J. Phokaew, personal communication, April $16,2017)$. The format has changed over time from giving stars (four stars as the full score) or giving a number such as 5 or 10 for top scores. Some people offer a grade from A to F. A common practice for Phokaew is to add extra plus signs to indicate his preference such as $\mathrm{A}+++++++++++++++$ +++++++++++++++ , sometimes shortened to A+30. Phokaew previously gave a normal grade of 10 or A. However, as there have been quite a few films which he gave an A, he wanted to make a distinction between these films and came up with a way to express it. Phokaew noted that "actually A with many plus signs and A with one plus sign are equal in terms of grade, but when I would like to promote a specific film, I would give more plus signs to suggest that I really vouch for this film" (personal communication, April 16, 2017).

Lertwiwatwongsa is another person who uses a grade system for a film. He said in an interview that this added plus sign attracts audiences to read the review; thus, the point is not the grade itself but a way to attract readers to read the actual review (W. Lertwiwatwongsa, personal communication, January 28, 2017). Lertwiwatwongsa also noted that these grades are personal preferences and not a standard measurement. The more the film made an impact on him, the higher the grade. One cinephile who takes the grade system seriously is Chayanin Tiangpitayagorn. He said that there are emotional nuances that should be taken into account in giving a grade to a film (C. Tiangpitayagorn, personal communication, July 24, 2017). Hence, 5 or 10 are not adequate. Currently, Tiangpitayagorn has an extensive grade range from the maximum of $\mathrm{A}+50$ to the lowest of $\mathrm{K}$ for Kuay (Kuay is a rude word in Thai language which literally means a man penis). Tiangpitayagorn emphasizes his personal preference in relation to the grade system similar to Lertwiwatwongsa. However, as his grades are very diverse, they sometimes cause heated debates. At one point, Tiangpitayagorn gave a very low grade for an animation to the extent that the filmmaker was upset. 
Despite the negative comments, it is important to note that these reviews often stimulate viewers to watch the films in order to find out if they are really as bad as the reviews suggested. For that reason, films that got F, $\mathrm{G}$ or $\mathrm{K}$ grades sometimes gained more audiences than those with $\mathrm{A}+50$. Through conversations with these cinephiles, it can be said that the affective dimension should not be undermined as a key part that drives the work of the members.

Aware of the difficulty in sorting their writings on Facebook, a number of cinephiles started posting their reviews as part of an album and naming it based on the year. For example, the Cinema 2017 album would include writings in relation to the films they saw in that year. When writing about a film, they would also post a photo along with the text to make it easier to find. Phokaew (personal communication. April 16, 2017) noted that he did not find this kind of practice amongst his cinephile friends from other countries. This method of organization has been adopted by Thai cinephiles to categorize their writings to fit with the platform. While each platform has a limited life span, the accumulated archival materials is another area worth exploring further in the future.

As there are more and more people writing about films they saw on Facebook, Lertwiwatwongsa (personal communication, January 28, 2017) has an idea of collecting these reviews together on his Facebook page called Kafe Lumiere. The name resonates with the film Café Lumiere (2005) by the Taiwanese auteur Hou Hsiao-Hsien. The inspiration reflects how Thai cinephiles have been inspired by East Asian filmmakers from Taiwan such as Hou and Filipino directors such as Lav Diaz. Kafe Lumiere collects writings as well as running its own activities. One example is a "Blogathon," a practice of compiling all reviews about a particular film (both Thai and foreign ones) which are in the cinema at the time. Lertwiwatwongsa and friends intend to use this as a way to encourage people to go to the cinema. The type of writings that Kafe Lumiere collected are diverse, including film analyses drawing on specific socio-cultural theories and film theories and person reflections. While there are other film pages available, Kafe Lumiere differs by collecting different views on cinema rather than the opinion of the owner of the page.

Despite the changing technologies and practices, one thing shared among the different generations of this group of Thai cinephiles is the belief that "if one finds something good, one has to share it" (as cited by Subyen, 2017). This sharing mentality is shaped by limited access of alternative films in Thailand. While technological development provides different channels for watching films, it is still difficult to find non-Hollywood movies, especially for those who live outside Bangkok. The cultural institutions 
previously mentioned continue to provide screenings of films from their own countries at specific times of the year but the majority of the screening venues are still in Bangkok. Subsequently, once the Bangkok-based cinephiles see some films that they are fond of, they find a way to spread the words and provide access to these works. This personal and collective drives have fostered cinephile culture among the members of the group as well as communicating their ideas to wider audiences.

\section{Conclusion}

This paper provides an overview and reflections of cinephile practices in Thailand from the 1980s until today based on interviews with a specific group of cinephiles. The early generation had the opportunity to see films beyond those screened at the cinema through cultural institutions located in Bangkok. During that time, the organization was led by expats who helped connect Thai cinephiles. Thai audiences began as a group by going to meals together after the screenings. Around 20 or so people met to exchange anything they knew about alternative cinema, which was considered hard to find and unusual. They also began writing film criticism, selecting films for screening and experimented with filmmaking.

The advent of home video distribution has shaped the landscape of film viewing all over the world, including in Thailand. In the late 1980s and 1990s, audiences started renting and buying films to watch at home. The screenings of alternative cinema in Bangkok also changed venues from cultural institutions to cineplexes. At this time a new group of cinephiles emerged via attending festivals to watch award-winning films. The conversations about cinema also expanded online facilitated by platforms such as a message board, instant messenger software, and social media. These platforms have become the link to connect people who were too shy to approach each other at the screenings. The growth of blogs around 2005 increased the number of cinephiles who later met up for screenings, went to dinners and talked about cinema in real life. Despite the changes, one of the shared characteristics of Thai cinephiles is to tell others the good stuff they have come across. This motivation helps expand cinephile culture to those outside Bangkok as well as wider audiences who may have come across one of their writings.

As webboard and blog have been replaced by social media, cinephiles continue to write and talk about cinema and use it as a way to promote their favorite movies. They continue to adapt to technological changes from producing video commentaries on short film marathon screenings and making a compilation of interviews and posted on YouTube. As writers switched to Facebook, cinephiles also found a way to categorize and archive 
their writings using the platform's own functions such as a Facebook album and a dedicated Facebook page. All of these activities shed light on the role of cinephiles not only as dedicated film viewers/film lovers but also as writers, promoters, and programmers. Productively, these practices help expand the history of Thai cinema beyond notable feature films to alternative works, short films and archives of memories. Creating large archives of diverse works, these practices provide a fertile source for future work on cinephile/fan studies, beyond the existing works on audience behaviors and satisfactions as found in previous literature on Thai film audiences. 


\section{References}

72 years Prince Chatrichalerm Yukol. (2014, November 28). Retrieved from https://pantip.com/ topic/32914376

Baikloy, P. (2003). Factors that influenced independent cinema viewing (Masters thesis). Chulalongkorn University: Bangkok.

Elsaesser, T. (2005) Cinephila or the use of disenchantment. In M. de Valck \& M. Hagener (Eds.), Cinephelia movies, love, and memory (pp. 27-44). Amsterdam: Amsterdam University press.

Kamsopa, S. (2007). Factor affecting movie viewing selection of Ramkhamhaeng University students (Masters thesis). Ramkhamhaeng University: Bangkok.

History of Thai film archive. (n.d.). Retrieved from http://www.fapot.org/en/about.php?mid=50

Jandeeriam, W. (2008). Factors affecting the short film viewing of viewers in Bang Kapi District, Bangkok Metropolis (Masters thesis). Ramkhamhaeng University, Bangkok.

Keathley, C. (2006). Cinephilia and history, or, the wind in the trees. Indiana: University Press.

Pang, L. (2006). Movie piracy as a technological threat to Hollywood. In L. Pang (Ed.), Cultural control and globalization (pp. 80-97). New York: Routledge.

Rosenbaum, J. (2010). Goodbye cinema, hello cinephile: Film culture in transition. Chicago: The University of Chicago Press.

Tangchonlatip, K. (2007). Bangkok: the forever primate city of Thailand. Journal of population and social studies, 2007, 20-39. Institute of population and social studies, Mahidol University, Nakorn Pathom.

Thai Film Archive. (2018, August 2). Dome Sukkhawong as the head of Thai Film Archive. Retrieved from https://m.facebook.com/notes/หอภาพยนตร์-thai-film-archive/โดม-สุขวงศ์-ในบทบาทผู้อำนวยการหอ ภาพยนตร์-องค์การมหาชน/1975640339152823/

\section{Notes}

1 All the interviewees cited in this article are informed and aware that their responses will be published.

${ }^{2}$ Gerard Fouquet was a film lecturer at Thammasat University. He was also a guest lecturer at Silpakorn University. He played an important role in coordinating with the French Embassy to bring Thai films to the Cannes International Film Festival in France.

SASAWAT BOONSRI is a film lecturer at the Communication Arts Division, Faculty of Information and Communication Technology, Silpakorn University, Thailand. He has a master degree from the Faculty of Communication Arts, Chulalongkorn University, Thailand. He has also been a member of Filmvirus since 2010. corresponding author: boonsri_2@silpakorn.edu)

WIKANDA PROMKHUNTONG is a lecturer in Film and Cultural Studies at the Research Institute for Languages and Cultures of Asia, Mahidol University, Thailand. She has completed her PhD in Film Studies at Aberystwyth University. Her thesis focuses on the global success of East Asian auteurs including Apichatpong Weerasethakul, Kim Ki-duk and Wong Kar-wai. Her previous writings in relation to auteur, cinephiles and star persona appeared in Participations: Journal of Audience \& Reception Studies, Routledge's Journal of Celebrity Studies and the Palgrave's Handbook of Asian Cinema. (corresponding author: wikanda.pro@mahidol.edu) 